\title{
ЛЕГЕНДЕ О СВЕТИТЕЉИМА И ЈУНАЦИМА У ПРИПОВЕДАЧКОЈ ПРОЗИ СА КОСОВА И МЕТОХИЈЕ $* *$
}

\begin{abstract}
У раду се бавимо предањима о јунацима и светитељима са Косова и Метохије, где показујемо које су специфичности приповедања на територији на којој се догодила Косовска битка и која је густо насељена манастирима. У предањима се уочава тенденција спајања култа јунака и светитеља, коју налазимо једино у легендама са Косова и Метохије, што указује на то да је средина, са својим специфичностима, утицала на обликовање одређеног жанра.
\end{abstract}

Кључне речи: легенде, предања, Косово и Метохија, јунак, светитељ, Косовска битка.

Бавећи се подробније народним приповеткама са Косова и Метохије, Владимир Бован уочава да су се оне највише сачувале јер је требало историјска сећања сачувати од заборава, а народна легенда је била погодан жанр за чување сећања на историјске личности и догађаје у колективном памћењу Косоваца. Легенда је временом модификована, тако да је, путујући кроз време, добила историјске наносе, али она, како истиче Владимир Бован, живи у народу „као остатак једном створених представа које су биле одраз одређеног нивоа свести једне људске заједнице мада у народној легенди често има сачуваних истинитих догађаја” (Бован 1980а: 15). Ненад Љубинковић наводи да се легенде везују „за 'повремене' историјске и митске личности, за њихове коње, оружје, за топониме на просторима којима су јунаци ходили" (Љубинковић 1998: 41). Још је Стојан Новаковић направио јасну границу између приповедака које воде порекло из стваралаштва архајских народа и приповедака из хришћанске књижевности (Новаковић 1867). Када је реч о приповеткама из хришћанске књижевности, он издваја и приче локалног ка-

\footnotetext{
*valentinapit@beotel.rs

** Рад је рађен у оквиру пројекта Српско усмено стваралаштво у интеркултурном коду (бр.178011), који финансира Министарство просвете, науке и технолошког развоја Републике Србије.
} 
рактера везане за ужи географски простор, чију ћемо специфичност показати на корпусу приповедака са Косова и Метохије.

Легенда у себи носи и елементе архаичне свести и историјске наносе, па је занимљив жанр за реконструкцију ова два значења. Легенде које су забележене на Косову и Метохији могле би се, како наводи Владимир Бован, поделити на легенде о местима и легенде о личностима. Он наводи и то да оне говоре о људима који се могу историјски пратити (Бован 1980а: 14-20). У легендама о местима тежиште је на причи о настанку неке грађевине, града, утврђења, насеља, манастира. Намеће се питање: на који начин је народни певач транспоновао историјске чињенице у усмено стваралаштво и како је дошло до њихове обраде у свести човека са овог поднебља? Како легенда тежи да објасни како се нешто збило, али на необичан начин, она је по својој структури, како наводи Нада Милошевић-Ђорђевић ,једноставнија и од бајке и од новеле" (Милошевић-Ђорђевић 2006: 53), док Мелетински сматра да је семантика мита и народне приче иста, ,ali sa prevlašću socijalnog koda” (Мелетински 1983: 267). Приповедачка проза на Косову и Метохији живела је упоредо са другим облицима усменог казивања, али је релативно касно записана, тек у другој половини 19. века. ${ }^{1}$

Прву збирку народних приповедака саставио је свештеник из Липљана, Дена Дебељковић. ${ }^{2}$ Косово и Метохија је изразито лирски крај, али је у народу живела и епска песма и сви облици приповедачке прозе. Разлог је разумљив, много је теже записивати народне приповетке, него говорне народне творевине (Бован 1980а: 7). Требало је „историјска сећања сачувати од заборава, а народна легеда као кратка прича била је врло погодна за задржавање у памћењу појединих личности и догађаја" (Бован 1980а: 15).

Пре него што уђемо у проблем култа јунака и светитеља у народним легендама, да напоменемо да Владимир Бован наводи да је народна легенда у овом крају била веома развијена и да има дугу традицију (Бован 1980а: 15). У овом жанру сачувано је сећање на историјске личности које су биле важне за опстанак колектива. Народ је у свом памћењу стварао представе о догађајима и јунацима, а легенда остаје да живи „као остатак једном створених представа које су биле одраз одређеног нивоа свести једне људске заједнице мада у народној легенди често има сачуваних истинитих догађаја". (Бован 1980a: 15). Оно што је важно за легенде, то је да говоре о људима које је историја познавала, а нама као истраживачима занимљиво је на који начин је историјска личност транспонована у легенду и шта је из живота личности било занимљиво за легендарно казивање. Легенда тежи да покаже како се нешто догодило у конкретном временском тренутку. О легендама са Косова и Метохије мало је писано. На овај богати корпус пажњу је скренуо Владимир Бован, нагласивши да је потребно подробније проучити овај жанр на територији на којој је вековима негован култ јунака и светитеља. Одјек Косовске битке био је веома снажан и присуство архетипа јунака и светитеља је сасвим

\footnotetext{
${ }^{1}$ Веселиновић 1895: 41-42; Босанска вила, 1898: 139.

2 Чува се у рукописној оставштини Д. Дебељковића у Архиву САНУ у Београду, улазни инвентар бр. 644, Етнографска збирка бр. 496.
} 
разумљиво у средини где је било велико поприште битке важне за опстанак колектива. Пећка патријаршија била је важан стожер опстанка српског народа, а народ, укорењен дубоко у вери, обликовао је у усменом предању свест о важности верског осећања, и посебно неговао култа светитеља. Ова два архетипа одређивала су етичку вертикалу етнопсихолошке заједнице која је опстајавала у тешким приликама живота под Турцима.

Легенде о светитељима: У легендама о светитељима доминантно је богато религијско искуство, јер је народни приповедач био у сталном додиру са црквама и манастирима, што је и потврдио транспонујући их у легенде. У легендама о светитељима приповеда се о апостолима и светитељима који не припадају српском простору, као и светитељима са нашег поднебља. Народ приповеда о Богу и Богородици, Светом Луки, Јовану Златоустом, Светом Илији, а када је реч о домаћим светитељима о Светом Сави, Светом Јоаникију, краљу Милутину. Они делају као обични људи. Ходају земљом, седају за совру, једу, причају, саборују, путују, искушавају људе, прерушавају се (Чајкановић 1994a: 42-50). Они се понашају као смртни људи, славе једни другога, пију вино они су медијатори између Бога и људи. Оно што се запажа у легендама о светитељима, то је да они имају хришћанска имена, али понекад и особине паганских божанстава. Показало се да се у овим легендама није извршила потпуна христијанизација, већ се иза њих често крију паганска божанства која су ушла у процес христијанизације. Они од Бога добијају задужења и у сталном су контакту са њим. Извештавају шта се догађа на Земљи, како се људи опходе једни према другима, а како према Богу. Светитељи чине чуда, имају моћ епифаније, искушавају људе прерушавањем у госте (Чајкановић 1994a: 42-50). Човек је опрезан када му дође гост, јер се веровало у епифанију, односно прерушавање неког божанства ради искушавања људи (Чајкановић 1994б: 261-291). У легендама о светитељима који нису са српског подручја уочавамо врло добро познавање библијских текстова, као и живота светитеља. У усменом приповедању запажамо стално присуство цркве, односно литургијског живота, што је и разумљиво, имајући у виду да се на територији Косова и Метохије налази много манастира. Сазнања о светитељима у колективно памћење ушла су из црквених кругова. Колико је хришћанство било дубоко укорењено у свести српског живља са овог простора, показује и присуство византијских светитеља, и то оних који су имали важно место у хришћанству. Издвојићемо Јована Златоустог, Светог Луку и Светог Илију. Оно што им је у легендама заједничко је то да чине чуда. У легенди објављеној у Цариградском гласнику, коју је забележио Александар Вулић у Неродимљу код Урошевца, Јован Златоусти је пре световни човек него светитељ. Родитељи га жене, али он се опредељује за монашки живот. Народни приповедач, по правилу, светитеља поставља у позицију грешника, а пут до светитељства је пут са препрекама, које морају да се савладају. Легенде о светитељима имају елементе народне бајке, а то је да свака иницијација захтева савладавање препрека уз присуство фантастичних мотива (Самарџија 1997: 175-193). Народни приповедач је светитеље приближио реалном животу. Свети Илија пуца из пушке, пре посвећења, дакле прво долази јуначка, 
а после тога светитељска иницијација. Правда се дели на земљи. Светитељи се налазе у додиру са паганским веровањем, као у предању о суђајама где се, како наводи Нада Милошевић-Ђорђевић, „тема о одређивању судбине приликом рођења појављује (се) у обе главне наративне категорије; у облику приповетке и у облику предања" (Милошевић-Ђорђевић 2006: 56-62). Народни приповедач је у предања инкорпорирао дидактички садржај и на свој начин тумачио појам греха. У предању о Светом Илији, као и у предању о непознатом светитељу радња иде у правцу градирања греха, где је, по народном веровању, највећи грех скудити девојку, па се предање „Највећи грех” завршава речима: „Нема већег греха на свету - веле - него кварити срећу заљубљенима, момку или девојци” (Цариградски гласник 2006: 106). Преко предања о светитељима народни приповедач је потенцирао хришћанске врлине које су биле етичке норме и део народне религије. У структури приповедања налазимо један слој који указује на семантику биља, посебно врбе, као дела тајног знања. То се огледа у легенди када светитељ саветује зликовца: „А кад ће ти Бог опростити грехове, то ћеш познати по томе, што ће ти одмах сува врба, у средини баште, листати" (Цариградски гласник 2006: 106). Оно што је занимљиво у предањима о светитељима је то да се иза њих често крију паганска бића. У предању „Свети Илија” светац заноћи у кући где се родило дете и где укућани на трећи дан, по народном веровању, чекају суђаје 3 да одреде судбину детету. Две доделе судбину, а трећа је преиначи, најчешће у позитиван исход. У овом предању две суђаје додељују детету судбину: „да испроси девојку преко једне велике воде у селу па да скупи сватове и да иде да је узме па кад се врати са невестом да падне од коња у исту реку и да се удави и невесту остави" (Цариградски гласник 2006: 141). Народни приповедач додељује Светоме Илији функцију треће суђаје, али он узима активно учешће у радњи, да би спасао младожењу. Он тиме преузима њену функцију и спасава младића сигурне смрти. У палимпсесту текста препознаје се и старији слој предања који је касније доживео христијанизацију тако што је трећа суђаја замењена Светим Илијом.

У предању о домаћим светитељима најбројнија су предања о Светом Сави и предања о локалним светитељима, попут Јоаникија Девичког. Предања о Светом Сави углавном се не разликују од предања у другим српским срединама (Чајкановић 1994а: 21-32). Свети Сава просеца прозоре, са другим светитељима путује по земљи и проповеда. У предањима о светитељима наглашена је дидактичност. Путовање и улажење у куће људи везани су за давање мудрих савета о свакодневним животним ситуацијама. Свети Сава у предању „Свети Сава и удаваче” доброј девојци жели злу срећу, а лошој

\footnotetext{
${ }^{3}$ „Суђаје су долазиле прве три ноћи по рођењу детета. Чиниле су то у поноћ, спуштајући се кроз димњак. Нису имале лична имена, али их је народ ипак разликовао. Најстарија би обично пожелела да 'Суђење' почне одмах, средња је то одлагала за сутрадан, а најмлађа је све померала за треће вече. Њено мишљење се уважавало, па је новорођенчету тек тада одређиван животни пут. И само суђење одвијало се истим редом. Прво би најстарија суђеница одредила детету неповољну судбину, средња би то ублажила, а најмлађа би нашла праву меру и њена реч би опет била одлучујућа. Дакле, све што би досудила најмлађа суђеница касније би се остварило" (Бандић 1991: 171).
} 
добру срећу, да би на крају објаснио светитељу који хода са њим своје речи на овај начин: „Тако треба: нигде два добра, нигде два зла” (Цариградски гласник 2006: 138). Свети Сава има посебан однос према вуковима. Веселин Чајкановић доводи у везу Светог Саву са вуковима, са митским претком, а тај пагански нанос налазимо у неколико ситуација и у предањима са Косова и Метохије. Нигде предање о Светом Сави и вуковима није ближе паганском слоју као у предању „Зашто вук бира најбољу овцу”. Свети Сава и вук заједно крећу у тор, имају пријатељски однос, разговарају, вук узима најбољу овцу, а Свети Сава благосиља. Овде је Свети Сава преузео функцију неког древног паганског божанства које је имало врховну власт у демонском свету вукова (Чајкановић 1994а: 32-37). Оно што одликује предања о светитељима са Косова и Метохије јесте да се на крају појављује издвојен закључак који је или дидактичког садржаја или је констатација зашто је нешто ушло у традицију, попут закључка из предања „Зашто вук бира најбољу овцу”, где на крају стоји: „Па отада је остало да вукови пробирају и хватају најбоље овце” (Цариградски гласник 2006: 139).

У легенди о Светом Јоаникију доминирају његове светитељске моћи, али је народни приповедач отишао и корак даље, увео га у јуначку иницијацију, која је само у предањима са Косова и Метохије изједначена са светитељском. Иако је светитељски ореол изнад јуначког, и нека врста највише иницијације, народном приповедачу било је веома важно да се светитељ докаже у боју. Он учествује у Косовском боју и стиче услов да постане светитељ, односно свети ратник. Ово је јединствени пример да светитељ, пре него што добије светитељски ореол, мора да учествује у бици која је важна за опстанак колектива, као што је Косовска битка, која је у нашем народу означена као „смак света” (Чајкановић 1994а: 353-375). Зато није ништа необично што је народни приповедач, живећи тамо где се догодила Косовска битка, изместио деловање светитеља из манастира на бојно поље. Функције јунака и светитеља сублимиране су у једно, оне чине јединствени подвиг овоземаљског и небеског. Тиме су предања са Косова и Метохије добила нанос који немају предања са других српских територија. Ово је показатељ да је средина и те како утицала на коначно обликовање жанра.

Легенде о личностима: Велики број легенди о световним личностима које су забележене на Косову и Метохији углавном се везују за историјске личности и бројније су од легенди о светитељима. Легенде о личностима углавном говоре о средњовековним историјским личностима: краљу Милутину, цару Урошу, Милошу Обилићу, Краљевићу Марку, Рељи Крилатици, Вуку Бранковићу, Ђурђевој Јерини, али има и легенди о личностима из новије историје, рецимо о вожду Карађорђу. У легендама о световним личностима транспоноване су личности које су се или доказале у боју или је у њиховој биографији постојао неки занимљиви, често интригантни детаљ. Оно што примећујемо у легендама о световним личностима то је да је народни певач имао посебан осећај према јунацима и слабијима. Он је на скалу својих вредности стављао највише етичке норме и имао је своје виђење историјских збивања. Тако је на Косову и Метохији живела месна легенда о краљу Вука- 
шину као убици цара Уроша, наследника цара Душана. Народни приповедач је унео у приповедање елементе усмене бајке. То је да ујак и сестрић крећу у лов, и када мајка, тражећи сина Уроша, наиђе на врбу, која „има везе са култом мртвих” (Чајкановић 1994в: 62), из које проговара сен цара Уроша: „Мајко, кога тражиш? Ево сам ја. Мајка угледа Уроша у врби рањива и на рани жабу припљену (од тога времена бог је благословио жабу те је и сад жива и мртва без икаквог смрада и мириса)" (Бован 1980б: 148). У предању о цару Урошу налазимо жанр у жанру - скаску о жаби и легенду о настанку назива места Модрић, Вртила, кладенца Царевца који постаје лековит. („Многи болесници иду на њу ради лечења па се мију, пију и купају на њему и још вежу по који конац на гранчицама, то значи да вржу и остане болест на томе месту, и оставе по коју пару) (Бован 1980а: 149). Овде је сачувано древно веровање да се болест лечи везивањем конца за дрво. У предању цар Урош ће после страдања добити светитељски ореол. Народни приповедач ће препознати мученичку смрт, посебно праведника који је страдао од туђе руке који на крају постаје светитељ. Овакав сиже се препознаје и у предању о цару Урошу. На крају наратива присутан је мотив сна, у којем мештанин Неродимља, по савету цара Уроша, узима врећу са његовим костима, креће ка северу, али се појаве пси „који су били удрили јуриш на њега и чим су га обколили одмах су полегали око човека, али се је одмах помислио за њега: или је био светац, или светитеља носи у врећу на плећи" (Бован 1980а: 150). На крају се казује да су његове мошти однете у Фрушку Гору: „Јашар паша је 1840. године порушио манастир св. Уроша а гробницу из манастира пренео у хамам у Приштини која се и данас тамо налази" (Бован 1980а: 150). Предање се завршава финалном формулом: „Оволико знам о Урошу ја, Рајко Дајич, из села Неродимље, стар осамдесет година. Записано 10. новембра 1880. године” (Бован 1980а: 150).

Запис о казивачу је драгоцен, посебно из разлога што су дати важни подаци о месту, времену, и живом сведоку усмене традиције. Занимљива појединост у другом предању о цару Урошу је што позајмљује из бајке готов модел који инкорпорира у текст, а то је претварање цара Уроша у голуба како би побегао у слободну Србију: „Није могао побећи од Турака другаче него се претвори у голуба, и плати једноме просјаку, те га овај у својој врећи пренесе крадом далеко у Србију, где није било Турака" (Бован 1980а: 150). Народном приповедачу су посебно занимљиве личности које су учествовале у Косовском боју: кнез Лазар, цар Мурат, Милош Обилић, војвода Јањић (Јоаникије Девички), Краљевић Марко. Народном приповедачу било је важно да остави сведочење о Милошу Обилићу које употпуњује његову епску биографију, која има нешто од древних наслага, а то је тајна његове снаге. Ако је тајна нечије снаге оно што је чинило структуру мита или бајке, то је у предању остао део древног приповедања. Тајну Милошеве снаге у месном предању открива баба, као хтонско биће иза којег се крије неко древно божанство доњега света. Народни приповедач каже: „Ту излегне та проклета баба, црна баба како црна крља" (Бован 1980а: 153). Оно што је карактеристично и за легенде о јунацима и о светитељима то је да су у њих инкорпориране легенде о местима. Тако ће се у легенди о Милошу Обилићу наћи легенда о месту Расково (где је 
Милошу раскован оклоп) или Бабин мос (односно Бабин нос, где је Милош бабу ухватио зубима за нос), затим Бакшија, место где су Турци Милошу одсекли главу, Милошева бања, Бошњаци. У легенди о Милошу Обилићу налазимо мотив јунака који држи своју главу под пазухом и трчи преко поља. Овај мотив из митологије говори о томе да је легенда са ове територије сачувала древни слој који се само трансформисао у конкретну историјску личност. У легендама о јунацима са Косова и Метохије налазимо јединствену појаву на српском простору, а то је да се јунак посвећује, односно да већ постојећи светитељ мора да се докаже у боју. Овај спој култа светитеља и култа јунака није случајан. Он само говори о томе колико је ово била специфична територија где се у усменом казивању најбоље рефлектовао начин живота. Два архетипа, архетип јунака и светитеља, нашла су места у жанру легенде. Необичну појаву у месној легенди да војвода Јанић, а не Милош Обилић, убија цара Мурата не можемо објаснити другачије него као потребу народног приповедача да споји ова два доминантна култа. Војвода Јанић, који убија цара Мурата, има исти оклоп као Милош Обилић, издаје га баба, носи своју главу под мишком, среће га девојка са својом мајком, а присутан је и табу ћутања (Бандића 1980: 105-112). Овде народни приповедач прати структуру легенде о Милошу Обилићу, али иде корак даље. Војводу Јанића сахрањује сестра: „Тако Јанић умакне до своје куће, негде између Митровице и Ђаковице, па ту падне, и онда га сестра сахрани. - То је подигнута црква светом Јанићију” (Бован 1980а: 155).

На Косову и Метохији забележена је и легенда о краљу Милутину, који гради манастир Грачаницу, где је дошло до транспозиције историјских чињеница и наслага митолошког колективног памћења као „производа стваралачког духа који зна језике и начине градње, надоградња ритуалних радњи” (Павловић 1999: 52).

Попут Јоаникија Девичког, и краљ Милутин, који је у предању градитељ манастира, мора да доживи иницијацију у борби са латинским краљем и на тај начин, како истиче Ерих Нојман, постаје узор „према коме се у човечанству стално живело" (Нојман 1994: 111). У предању су Латини хтонска сила коју треба савладати приношењем жртве, а то је сам краљ Милутин који се жртвује у борби као симболична замене за жртву, јер се ниједна грађевина не може одржати без приношења жртве (Павловић 2002: 15-35). Краљ Милутин, који је градио манастир Грачаницу, као историјска личност, поред четрдесет других, ушао је у легенду баш као градитељ и народном приповедачу било је важно да приповеда о овом највећем задужбинару Немањића. Он у овој легенди приноси жртву у борби, а у архаичној свести грађевина се не може одржати без приношења жртве јер „храм представља imago mundi, зато што је Свет, као дело богова, сакрализован (Елијаде 2003: 104). Борба са латинским краљем је симболична замена за жртву чији ће резултат бити градња манастира. Народни приповедач је и у овом предању спојио култ јунака и светитеља. Краљ Милутин се прво доказује у боју да би ушао у сакрални простор градње храма који се, како наводи Миодраг Павловић, „устоличује на границу живота и смрти” уз приношење оснивачке жртве која 
је неопходна на почетку сваког зидања, ,jер неоспорно је било жртвовање за сам настанак храма, и о томе извештавају многа митска и фолклорна предања" (Павловић 2000: 163).

Приповедајући о јунацима који су били историјске личности полази се од конкретне историјске чињенице, која се транспонује у већ формирани модел митолошког погледа на свет. У митолошкој сфери сталне борбе светлости и таме, који активно учествују у стварању света и појава, краљ Милутин, као учесник у земаљској космогонији одговара, како би рекао Ерих Нојман, „првобитној митологији простора” (Нојман 1994: 92). И јунак и светитељ, краљ Милутин, учествује у уређивању простора самом градњом храма, где долази до сакрализовања профаног. Као и у легенди о цару Урошу и краљ Милутин долази у контакт са водом, као препреком својственом бајци, а која у неким предањима после додира са светитељем постаје лековита. ${ }^{4}$ У народу је живело и предање о Краљевићу Марку, који је у тамници, али га цар ослобађа јер му је пут заузео ,један Новак у Качаник” и нема јунака који може да га савлада осим Краљевића Марка: Марко поседује оне елементе своје епске биографије карактеристичне за епску народну песму. Он је турски вазал који је често у тамници због непослушности, има чудесну снагу, штити нејач, савладава јунаке који су његови побратими, али их пушта, а цару односи њихове капе као доказ да их је погубио. Међутим, легенде о Краљевићу Марку нису тако развијене као о осталим јунацима, посебно онима који су учесници Косовског боја. У предањима о светитељима и јунацима наслућује се долазак последњих времена, о којима Веселин Чајкановић говори као о интернационалном мотиву о смаку света (Чајкановић 1994б: 353-375), а који се у српском етносу означава као време Косовске битке. Народни приповедач у предањима о настанку градова и сакралних грађевина чува архаичне представе о градњи, али и елементе мита о хероју - „узор преме коме се мора живети и преме коме се у човечанству стално живело” (Нојман 1994: 111).

Овде налазимо тренутак епске сакралности јер „разни су тренуци у којима јунаци настају, али предање о јунаштву једно је и сакрално” на шта упућује Миодраг Павловић (2002: 120).

Најбројније су оне легенде у којима се приповеда о јунацима и светитељима који су живели на територији важној за опстанак целог колектива, а посебно оне у којима се спаја култ јунака и светитеља. Корпус предања са Косова и Метохије још увек није довољно истражен, јер су се научни истраживачи углавном фокусирали на записе Вука Стефановића Караџића. Да би се имао потпуни увид у генезу народних предања Срба потребно је подробније истраживање овог богатог корпуса, чиме би се добио увид у специфичност усменог казивања свих варијетета српског живља.

\footnotetext{
${ }^{4}$ По народном веровању, вода једним делом одлази у пакао и тамо гаси силну ватру. Ако не би тамо отицала, онда би потопила свет. Велике воде скупљају се негде на крају света, тамо где се небо наслања на земљу (Кулишић и др. 1970: 73).
} 


\section{ИЗВОРИ}

Бован 1980а: В. Бован, Народна књижевност Срба на Косову, народне приповетке 1, Приштина: Јединство.

Бован 1980б: В. Бован, Народна књижевност Срба на Косову, народне приповетке 2, Приштина: Јединство.

Босанска вила 1898: Босанска вила: лист за забаву, поуку и књижевност, год. 8, бр. 8.

Дебељковић, Д. Дебељковић, рукописна оставштина у Архиву САНУ у Београду, улазни инвентар бр. 644, Етнографска збирка бр. 496.

Цариградски гласник 2006: Српске народне умотворине са Косова и Метохије на странииама Цариградског гласника (прир.) В. Бован, Исток-Лепосавић, Дом културе „Свети Сава”.

\section{ЛИТЕРАТУРА}

Бандић 1991: Д. Бандић, Народна религија Срба у 100 појмова, Београд: Нолит. Веселиновић 1895: М. Веселиновић, Поглед на Косово, Београд.

Елијаде 2003: М. Елијаде, Свето и профано, Сремски Карловци - Нови Сад: Издавачка књижарница Зорана Стојановића.

Љубинковић 1988: Н. Љубинковић, Историја и фолклор, Зборник Филолошког факултета, књ. 8, Приштина: Филолошки факултет.

Мелетински 1983: Е. M. Meletinski, Poetika mita, Beograd: Nolit.

Милошевић Ђорђевић 2006: Н. Милошевић-Ђорђевић, Од бајке до изреке, Београд: Друштво за српски језик и књижевност Србије.

Новаковић 1867: С. Новаковић, Историја српске къижевности, Београд.

Нојман 1994: Е. Нојман, Историјско порекло свести, превео Григорије Ерњаковић, Београд: Просвета.

Павловић 2000: М. Павловић, Поетика жртвеног обреда, Београд: Нолит.

Павловић 1999: М. Павловић, Свечаности на платоу, Београд: Просвета.

Самарџија 1997: С. Самарџија, Поетика усмених прозних облика, Београд: Народна књига, Алфа.

Кулишић и др. 1970: Ш. Кулишић, П. Ж. Петровић, Н. Пантелић, Српски митолошки речник, Београд: Нолит.

Чајкановић 1994а: В. Чајкановић, О врховном богу у старој српској религији, Београд: СКЗ, БИГЗ, Просвета.

Чајкановић 1994б: В. Чајкановић, Студије из српске религије и фолклора, Београд: СКЗ, БИГЗ, Просвета, Партетнон М.А.М.

Чајкановић 1994в: В. Чајкановић, Речник српских народних веровања о биљкама, Београд: СКЗ, БИГЗ, Просвета, Партетнон М.А.М. 


\title{
Валентина Д. Питулич \\ ЛЕГЕНДЫ О СВЯТЫХ И ГЕРОЯХ В НАРРАТИВНОЙ ПРОЗЕ КОСОВО И МЕТОХИИ
}

\author{
(Резюме)
}

Развитие народной прозы Косово и Метохии шло параллельно с развитием народной поэзии, но записываться эти рассказы стали намного позже. В данной статье мы будем анализировать функции героя и святого в народных легендах, которые записаны на территории, сохранившей архаичную структуру сознания. А на территории Косово и Метохии в коллективном самосознании активно использовались архетипы героя и святого, поэтому мы постараемся показать процесс транспозиции исторических персонажей в легенду и какое место они занимали на территории с ярко выраженным религиозным архетипом.

В статье мы будем анализировать функции героя (Королевич Марко, Милош Обилич) и функции святого (святой Иоаникий Девичкий, святой Илья, Святой Сава), которые в нарративной прозе Косово и Метохии получили несколько иные характеристики, отличные от тех, которые встречаются в других областях. Также мы сделаем попытку описать общественно-историческую ситуацию, которая повлияла на процесс формирования народных легенд о героях и святителях, чьи образы весьма часто переплетаются и взаимозамещаются, а народном сознании выступаяют в единой функции - сохранения идентитета. 